Uluslararası Mühendislik

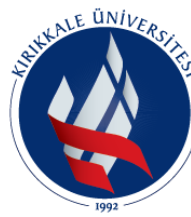
FAKÜLTESI

Araştırma ve Geliştirme Dergisi

UMAGD, (2019) 11(1), 109-123.

International Journal of

Engineering Research and

Development

10.29137/umagd.385030

Cilt/Volume:11 Sayı/Issue:1 Ocak/January 2019

Araştırma Makalesi / Research Article

\title{
Türkiye'deki Endüstri Mühendisliği Eğitiminin Mezun Görüşlerine Dayalı Analizi
}

\author{
Analysis Based on Graduation Opinions of Industrial Engineering Education in \\ Turkey
}

\author{
Ukbe Üsame Uçar ${ }^{1}$ iD , Selçuk Kürşat İşleyen ${ }^{2}$ \\ ${ }^{1}$ Fırat Üniversitesi Mühendislik Fakültesi Endüstri Mühendisliği Bölümü, 23000 Elazlğ, TÜRKIYYE \\ ${ }^{2}$ Gazi Üniversitesi Mühendislik Fakültesi Endüstri Mühendisliği Bölümü, 06000 Ankara, TÜRKIYE
}

Başvuru/Received: 28/01/2018

Kabul/Accepted: $15 / 11 / 2018$

Son Versiyon/Final Version: 31/01/2019

\begin{abstract}
Öz
Türkiye’ de her yıl binlerce öğrenci farklı üniversitelerin endüstri mühendisliği bölümünden mezun olmakta ve çeşitli sektörlerde iş hayatına başlamaktadır. Öğrenciler, üniversitelerinden aldıkları eğitim ve vizyon sayesinde çalıştıkları sektörlerde başarılı olabilmektedir. Alınan eğitimlerin değerlendirilmesi ise ancak mezun olduktan sonra anlaşılabilmektedir. Bu çalışmada, Türkiye' de endüstri mühendisliği eğitimi veren üniversitelerin değerlendirilmesi ve karşılaştırılması için mezun görüşlerine dayalı bir anket çalışması yapılmıştır. Anket çalışmasının güvenilirliğinin test edilmesinde Cronbach Alpha testi, elde edilen sonuçların analiz edilmesinde ise istatistiksel metotlar kullanılmıștır. Bu çalışma ile Türkiye' de verilen endüstri mühendisliği eğitiminin mevcut durumunu analiz edip, güçlü ve zayıf yönlerinin tespit edilmesi amaçlanmış, bu sayede, Türkiye' de, endüstri mühendisliği eğitiminin daha iyi bir yere taşınmasına katkıda bulunulması hedeflenmiş̧ir.
\end{abstract}

Anahtar Kelimeler

"Endüstri Mühendisliği, Anket Çalışması, İstatistiksel Analiz”"

\begin{abstract}
Every year in Turkey, thousands of students graduate from industrial engineering departments of different universities and start their business life in various sectors. Students are able to succeed in the sectors they work with thanks to the education and vision they receive from their universities. The evaluation of the receiving education can only be understood after graduation. In this study, a questionnaire study based on graduate opinions was conducted for the evaluation and comparison of universities providing industrial engineering education in Turkey. Cronbach Alpha test was used to test the reliability of the questionnaire and statistical methods were used to analyze the results. This study aims to analyze the current situation of industrial engineering education in Turkey and to identify strengths and weaknesses of this education. In this way, it is desirable to contribute to improve the industrial engineering education in Turkey.
\end{abstract}

Key Words

"Industrial Engineering, Questionnaire Study, Statistical Analysis" 


\section{GİRiş}

İnsanlar çeşitli sınavlardan geçip hayallerini gerçekleştirmek ve bir meslek sahip olmak adına üniversiteler kazanmakta, çok az bir bilgi ile girdikleri bölümlerden, alanında uzman, mesleğinin gerektirdiği donanımlara sahip bireyler olarak topluma kazandırılmaktadırlar. Çoğu birey hayatının tamamında bu meslek ve üniversitenin kazandırdığı yeteneklerle yaşamını devam ettirmekte, gerek hayatın getirdiği şartlar gerekse de zamansal durumlar nedeniyle bu becerilerin üzerine çok az bir katkıda bulunabilmektedirler. Bu bağlamda üniversiteler, mesleğine hakim, donanımlı, vizyon ve özgüven sahibi, inisiyatif alabilen bireylerin topluma kazandırılması açısından büyük bir önem arz etmektedir. Bu özelliklere sahip bireyler, kariyerleri başta olmak üzere hayatlarının büyük çoğunluğunda başarılı ve mutlu olmakta, bu donanımlardan yetersiz bireyler ise eksik kısımlarını tamamlamak için oldukça zaman ayırmakta, iş hayatında kolay rekabet edememekte ve yaptıkları işlerde başarı oranları düşük olmaktadır. Genel olarak baktığımızda ise donanımlı bireylerin çokluğu, ülke ekonomi ve refahı açısından büyük bir öneme sahip olmakta, bu bireylerin yoğunlukta olduğu Kanada, İngiltere, Almanya, Amerika ve Avustralya gibi ülkelerde yaşam kalitesi ve başarı durumunun tatmin edici düzeyde olduğu gözlemlenmektedir. Bu ülkelerin tercih edilmesinin temel sebebi eğitim faaliyetlerin yanında öğrencilere sağlamış olduğu sosyal imkânlar ve farkındalık yaratan çeşitli donanımlar olmaktadır.

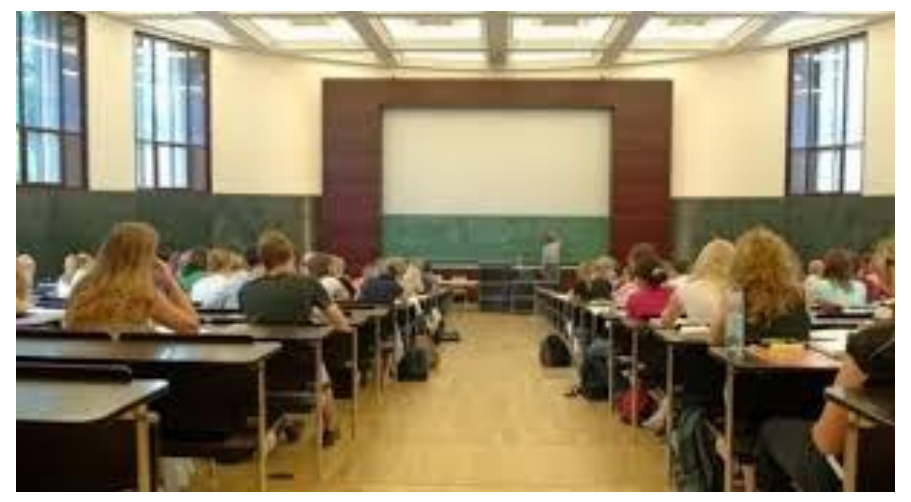

Şekil 1. Üniversitede Verilen Örnek Bir Eğitim

Günümüzde teknoloji ve bilim çok hızlı bir şekilde ilerlemekte, mevcut bilgilerin yerlerini yenileri almakta ya da hiç olmayan kavramlar, bilimsel literatüre dâhil olmaktadır. Bu yeni sistemler, sosyal ve iş hayatına hızlı bir şekilde entegre olmakta, bu hızlı gelişmeleri takip eden ve farkında olan bireyler, çağı yakalayıp başarılı bir kariyere ve yaşama sahip olmaktadır. Eğitim sistemi de bu hızlı değişimlerden etkilenmekte ve kendini güncelleme ihtiyacı doğmaktadır. Eski bilgiler ya da artık kullanılmayacak bilgiler ile eğitimi devam ettirmek, mesleğinde yetersiz bireylerin topluma katılmasına neden olmakta, bu durum yapılan iş ve faaliyetleri olumsuz etkilemektedir.

Üniversitelerce verilen eğitimin yeterliliği, yetişen bireylerin donanımı ve başarısı ise ancak öğrencinin mezun olduktan sonra iş hayatındaki başarımına göre tespit edilebilmektedir. Bunu en iyi tespit edecek kişileri ise mezun öğrenciler oluşturmakta, bu öğrenciler aldıkları eğitim ile iş hayatının gerçeklerini karşılaştırarak yeterliliği ile pozitif ve negatif yönlerini tespit edebilmektedir. Bu çalışmada, Türkiye’ deki üniversitelerde verilen endüstri mühendisliği eğitimi hakkında genel bir bilgi sahibi olunması, eğitimin avantajlı ve dezavantajlı yönlerinin tespit edilmesi ve iş hayatındaki beklentilerin ortaya konulması adına ilgili bölümden mezun öğrencilere bir anket çalışması uygulanmıştır. Sonuç olarak ilgili bölümün daha iyi tanımlanması, mevcut durumun detaylı analiz ve yapılabilecek iyileştirmeler adına bir fikir oluşturulması amaçlanmışıtır.

Literatürde endüstri mühendisliği eğitiminin ve çalışma alanlarının değerlendirilmesi üzerine birçok çalışma bulunmaktadır. Erginel ve ark.(2013), 2013 yaptıkları çalışmada TMMOB (Türk Mühendis ve Mimar Odaları Birliği) Makina Mühendisleri Odası'na kayıtlı 437 endüstri mühendisinin anket sonuçlarına dayalı olarak Türkiye' deki endüstri mühendisi çalışanlarının mevcut durumunu analiz etmeye ve geleceğe yönelik çıkarımlarda bulunmaya çalışışlardır. Ercan ve ark.(2005), çalışmalarında dünyada ve Türkiye' de endüstri mühendisliğinin başlangıcı, gelişimi ve kapsamı hakkında genel bir bilgi vermiştir. Mummolo, çalışmasında Avrupa Birliğindeki endüstri mühendisliği eğitimini değerlendirmiş, mezunların gereksinimlerini ve istihdam alanlarını analiz etmiştir. Avrupa' daki yüksek eğitime ve bu eğitimin cazip hale getirilmesi üzerine tespitlerde bulunmuş, endüstri mühendisliği eğitimindeki firsatları araştırmıştır. Sonuç olarak endüstri mühendisliği ders programının modern ve yenilikçi endüstriyel sektörlerden gelen bilgi ve talepler doğrultusunda şekillenmesi gerektiğini belirtmiştir. Buzacott (1984) çalışmasında, endüstri mühendisliği eğitimi adına bazı problemler tespit etmiş ve bunlara ilişkin çözüm önerilerinde bulunmuştur. Buzacott (1984), endüstri mühendisliği eğitiminin teknolojik gelişmeler doğrultusunda güncellenmesi gerektiğini belirtmiştir. Chen ve ark. (2005), çalışmalarında çeşitli endüstri mühendisliği müfredatlarını araştırmış ve öğrencinin yaratıcıllğını teşvik eden bir müfredatın bulunmadığını belirtmişlerdir. Bu meslekte en önemli şeyin problem çözme becerisine sahip yaratıcı öğrencilerin

${ }^{1}$ https://www.google.com.tr/search?q=\%C3\%BCniversite+e\%C4\%9Fitim\&rlz=1C1NDCM trTR717TR717\&source=lnms\&tbm=isch\&sa=X\&ved=0ahUKEwiC $\underline{\text { 5YSz467XAhWEOsAKHaMlANsQ AUIDCgD\&biw=1366\&bih=662\#imgrc=hzYidfsD59m4mM }}$ 
yetiştirilmesi gereksinimini olduğunu ifade etmiş ve bu bağlamda üç yeni ders geliştirdiklerini belirtmişlerdir. Bu dersleri ise Endüstriyel İletişim(İndustrial Communication), Yaratıcı Problem Çözme (Creative Problem Solving) ve Bilimsel Araştırma Metodoloji(Scientific Research Methodology) adları ile isimlendirmişlerdir. Elsayed (1999) çalışmasında, endüstri mühendisliğinin doğuşuna genel bir bakış açısı yapmış, üretim teknolojilerinde meydana gelen gelişmeler ve sektörün talebini karşılamak adına müfredatta yapılması gerekenleri detaylı bir şekilde analiz etmiştir. Biles (1991), çalışmasında endüstri mühendisliğinin bilimsel temellerini özetlemekte ve bu bilim dalına dayalı olarak endüstri mühendisliği eğitimi için bir yaklaşım önermektedir. Ellis ve Pun (2010), çalışmasında endüstri mühendisliği eğitiminin mevcut durumunu analiz etmiş, eğitimdeki trendin hangi yönde olduğu hakkında bilgi vermiş ve mevcut programı geliştirmek adına yeni bir program önermiştir. Schutte ve ark.(2016), çalışmalarında Güney Afrika' daki endüstri mühendisliğinin içeriği ve tarihsel gelişimi hakkında bilgi vermiş, bu bilim dalını, üniversite çalışmaları, nitelikleri ve sektördeki kullanım alanları gibi bakış açıları altında analiz etmiştir. Kuo (2003) çalışmasında, endüstri mühendisliğinin genel tanımını yapmış, geçmişteki durumuna bir bakış açısı sağlamış, son olarak hem mevcut durum hem de gelecek durumuna ilişkin değerlendirmelerde bulunmuştur. Köksal ve Eğitman (1998), çalışmalarında Orta Doğu Teknik Üniversitesinde Endüstri Mühendisliği eğitiminin kalitesini geliştirmek için bir Kalite Fonksiyon Yayılımı(QFD) yaklaşımı geliştirmiş, farklı alanlardan paydaşların oluşturduğu bir grubun endüstri mühendisliği bölümünden mezun birinden beklentilerini ve ilgili bölümün gereksinimlerini, mülakatlar ve araştırmalar yoluyla belirlemeye çalışmışlardır. $\mathrm{Bu}$ çalışmalar haricinde endüstri mühendisliği başta olmak üzere çeşitli mühendislik eğitimi üzerine birçok çalışma bulunabilmektedir. Analiz edilen çalışmalardan hareketle, genel bir kanının endüstri mühendisliği eğitiminin teknolojideki gelişmelere bağlı olarak eğitim müfredatının sürekli gelişmesi ve güncellenmesi gereken bir bilim dalı olduğu anlaşılmakta, çalışma sahiplerinin de mevcut sistemi geliştirmeye yönelik bir çaba içerisinde olduğu anlaşılmaktadır.

Çalışmanın ikinci bölümünde ele alınan anket çalışmasının özellikleri ifade edilmekte, üçüncü bölümde anketin değerlendirilmesinde ve yorumlanmasında kullanılan metodolojiler takdim edilmekte, dördüncü bölümde ise genel bir değerlendirme yapılmakta ve gelecek çalışmalara ilişkin önerilerde bulunulmaktadır.

\section{ANKET ÇALIŞMASI}

Bu çalışmada, Erginel ve arkadaşlarının 2013 yılında yapmış oldukları çalışma temel alınarak, Türkiye'de eğitim veren endüstri mühendisliğinden mezun öğrencilere sosyal medya ve çeşitli bloglar üzerinden bir anket çalışması düzenlenmiş, anketlerin hazırlanması ve değerlendirilmesinde Google Form' dan yararlanılmıştır. (Erginel ve arkadaşları;2013) Çalışma, temelde Erginel ve ark.(2013), çalışmalarından hareketle hazırlanmakta, farklı parametrelerin ve çeşitli performans ölçütlerin dikkate alınması nedeniyle bu çalışmadan ayrılmaktadır. Bu çalışmayı, diğer çalışmadan ayıran temel özelliklerden bazıları şu şekilde olmaktadır.

- Bu çalışmada dikkate alınan üniversite sayısı, Erginel ve ark., yaptıkları çalışmadan daha fazladır (Erginel ve arkadaşları; 2013)

- Erginel ve ark., çalışmalarında genel olarak endüstri mühendisliği mezunlarının hangi alanda çalıştıkları ve mesleğin gelecekteki durumları üzerine odaklanmışken, bu çalışmada alınan lisans eğitimi, akademik personelin yeterliliği, üniversitenin sağlamış olduğu imkanlar, öğretim elemanı-öğrenci ilişkisi gibi mevcut eğitim sisteminin ve öğretim elemanlarının olumlu ve olumsuz yönleri tespit edilmeye çalışılmıştır (Erginel ve arkadaşları;2013)

- Bu çalışmada, diğer çalışmadan farklı olarak mezunların bakış açısına göre Türkiye' deki endüstri mühendisliği eğitimi veren bölümlerin birbirlerine göre tercih edilebilirlikleri ve üstünlüklerinin belirlenmesi amaçlanmıştır.

- Bahar şenliklerinin yapılması, uluslararası anlamda yeterlilik gibi sosyal ve kişisel konuların dikkate alınması da bu çalışmayı, diğer çalışmadan ayıran özelliklerden biri olmaktadır.

Çalışmanın ilerleyen bölümlerinde yapılan anket çalışmasının demografik özelliklerinden bahsedilmekte ve anket sonuçları detaylı bir şekilde analiz edilmektedir.

\subsection{Anket Çalışmasının Özellikleri}

Anket çalışmasına çeşitli üniversitelerden birçok mezun katılmıştır. Bu kısımda anket çalışmasında dikkate alınan üniversiteler, mezunların çalıştığı sektör ve pozisyonlar gibi demografik özelliklere ilişkin bilgiler sunulmuştur. Ankete 66 farklı üniversitenin ismi yazılmış ve bunun dışında kalan üniversiteler diğer başlı̆̆ altında değerlendirilmiştir. Toplamda 67 farklı üniversiteden 224 mezun öğrencinin ankete ilişkin değerlendirmeleri dikkate alınmıştır. Anketin güvenilirliğini test etmek için Cronbach Alpha testinden faydalanılmıştır.

Cronbach Alpha testi, önceden belirlenmiş ölçekler doğrultusunda düzenlenmiş olan ankete verilen cevapların tutarlığını ölçen istatistiksel bir yöntemdir. Bu analiz de tüm sorular için ortalama bir alfa değeri bulunur ve bu değerin 0,6 dan büyük olmas1 istenir. 0,6 den düşük olması, anketin düşük güvenilirliğe sahip olduğunu, 0,8 den büyük olması ise yüksek güvenilirliğe sahip olduğunu göstermektedir. Bu çalışmada güvenilirlik değeri 0,727 olarak çıkmış, bu değer yapılan anket çalışmasının orta düzeyde güvenilir olduğunu ve istatistiksel açıdan kabul edilebilir düzeyde olduğunu göstermektedir. (Yaşar; 2014)

Ankete katılan üniversitelerin adları şekil 2 de gösterilmekte, en fazla katılım gösteren ilk yirmi üniversite ve özellikleri ise şekil 3 de ifade edilmektedir. 


\begin{tabular}{|c|c|c|c|}
\hline - ABDULLAH OUL ONIVERSITESI & - BASSKENT CNEVERSITESI & - DoGUS UNIVERSITESI & - GAZIANTEP UNMERSITESI \\
\hline - aOANA BILLU VE TEKNOLONI UN & - BAYBuRT ONIVERSITESI & DOKUZ EYOL ONIVERSITESI & - GIRNE AMERIKAN ONIVERSITESI \\
\hline C AKSARAY ONIVERSITESI & - BEYKENT UNEVERSITESI & - dUMLUPINAR UNDEVESITESI & - HACETTEPE ONIVERSITESI \\
\hline - ANADOLU ONIVERSITESI & BOGAZICI UNIVERSITESI & DUZCE ONIVERSITESI & ISIK CNIVERSITES! \\
\hline - ATATURK UNIVERSITESI & - CELA BAYAR ONDERSITESI & - ERCIVES UNIVERSITESI & - HASAN DOGRAMACI BLUKENT UNI \\
\hline - ATILM UNIVERSITESI & - CANiKaYA UNIVERSITESI & - ESKIŞEHIR OSIMANGAZI ONIVER & - IstAMBUL BILCI UNIVERSITES| \\
\hline - BAHÇESEHIR ONVVERSITESI & - CUKURONA ONIVERSITESI & - galatasarar ONIVERSITESI & - ISTANBUL KuLTUR UNIVERSITESI \\
\hline - BALKESIR ONIVERSITESI & - DOGU AKDENIZ UNIVERSITESI & - gaZI UNIVERSITESI & - ISTAMBUL TEKNIK ONIVERSITESI \\
\hline - ISTANEUL \$SEHR ONIVERSITESI & - KOCAEUI ONIVERSITESI & - ONDOKUZZ MAYIS UNDERSITESI & - SOFYA TEKONK UNIVERSITESI \\
\hline ISTANBUL TICARET UNEVERITESI & - KOC UNIVERSITESI & - OKAN UNNERSITESI & - SOLEYMAN DEMIREL UNIVERSIT. \\
\hline - ISTANEUL ONIVERSITESI & - KTO KARATAY ONIVERSITESI & - ORTA DOGU TEGUKK UNIVERSIT. & - TOQB EKONOMI VE TEKNOCOII \\
\hline - izuir exonomi universitesi & O MALTEPE UNIVERSITESI & - OZYEGIN UNIVERSITESI & - TORK_ALMAN ONEVERSITESI \\
\hline - kadir has UNiversitesi & - MARMARA ONVEERSITESI & - PAMUKKALE CNIVERSITESI & - ULUDAG UNEVESSITESI \\
\hline KARABOK UNIVERSITESI & DEF ONIVERSITESI & - SABAWCI UNIVERSITESI & Y YNONA UNIVERSITESI \\
\hline - KARADENIZ TEKNIK UNIVERSITESI & - NAMIK KEMAL ONIVERSITESI & - SAKACYA UNIVERSITESI & - yasar uneversitest \\
\hline - KIRIKKALE CNIVERSITESI & - NECMETTIN ERBAKAN UNEVRSI & SELCCUK LNEVERITESI & YEDITEPE CNIVERSITESI \\
\hline
\end{tabular}

Şekil 2. Ankete Katılan Üniversitelerin İsimleri.

Şekil 3 e göre en fazla katılım gösteren üç üniversitenin sırasıly $\% 17$ ile Gazi, $\% 9,4$ ile Kırıkale ve $\% 8,5$ ile Erciyes olduğu görülmektedir.

\begin{tabular}{|c|c|c|c|c|c|}
\hline Sira & Universite Adı & Katılım Oranı & Sira & Üniversite Adı & Katilım Oranı \\
\hline 1 & Gazi & $\% 17$ & 11 & Karabuk & $\% 3,1$ \\
\hline 2 & Kurikkale & $\% 9,4$ & 12 & Atatürk & $\% 2,7$ \\
\hline 3 & Erciyes & $\% 8,5$ & 13 & Çukurova & $\% 2,7$ \\
\hline 4 & Balukesir & $\% 5,8$ & 14 & Yıldız Teknik & $\% 2,2$ \\
\hline 5 & Kocaeli & $\% 5,4$ & 15 & Pamukkale & $\% 2,2$ \\
\hline 6 & Selçuk & $\% 4,9$ & 16 & Diğer & $\% 2,2$ \\
\hline 7 & Sakarya & $\% 4,5$ & 17 & Istanbul & $\% 1,8$ \\
\hline 8 & Osmangazi & $\% 3,6$ & 18 & Gaziantep & $\% 1,8$ \\
\hline 9 & ODTU & $\% 3,1$ & 19 & Uludağ & $\% 1,8$ \\
\hline 10 & Dokuz Eylal & $\% 3,1$ & 20 & Suleyman Demirel & $\% 1,8$ \\
\hline
\end{tabular}

Şekil 3. Ankete En Fazla Katılım Gösteren İlk Yirmi Üniversite.

Ankete katılan mezunların çalıştığı sektörler ise şekil 4 de belirtilmektedir. Şekil 4 e baktığımızda, yapılan anket çalışmasına göre endüstri mühendislerinin genel olarak üretim sektöründe çalıştığını, bu sektörü ise hizmet sektörünün takip ettiğini görmekteyiz.

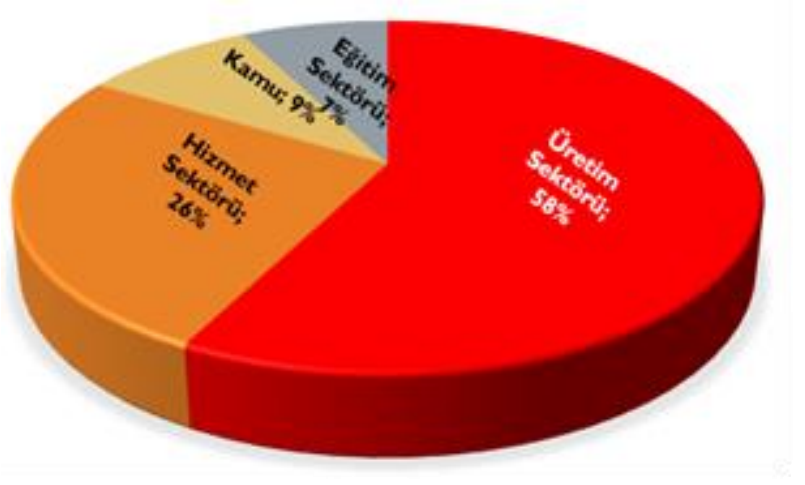

Şekil 4. Endüstri Mühendislerinin Çalıştığı Sektörler.

Endüstri mühendislerin bulundukları sektörlerde hangi pozisyonda çalıştıkları ile ilgili soruya verilen cevaplar ise şekil 5 de belirtilmektedir. $\mathrm{Bu}$ sonuçlara göre yapılan anket çalı̧̧̧asından hareketle endüstri mühendislerinin en fazla mühendis pozisyonunda, en az ise genel müdür pozisyonunda çalıştığı anlaşılmaktadır. 


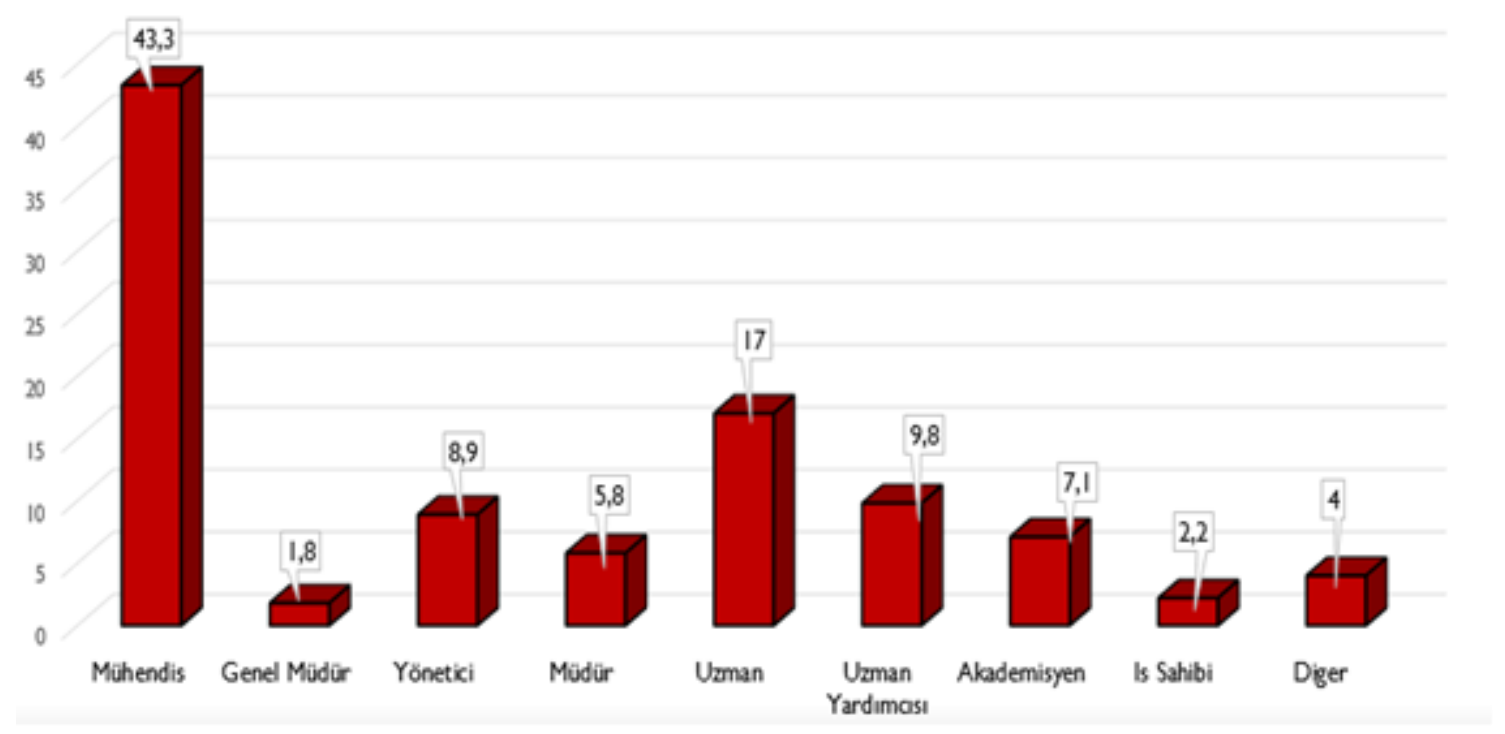

Şekil 5. Endüstri Mühendislerinin İş Yerlerinde Çalıştı̆ı Pozisyonlar

\subsection{Endüstri Mühendisliği Eğitimine İlişkin Anket Sonuçlarının Analizi}

Bölüm 2.1 de ankete katılan kişilere ilişkin demografik özellikler takdim edilmişti. Bu bölümde ise ankete katılan mezunların, endüstri mühendisliği eğitimi ile ilgili sorulara verdiği cevaplar analiz edilmiștir. Ankette mezunlara lisans eğitimini yeterli bulup bulmadıkları sorulmuş ve sonuçlar şekil 6 da belirtilmiştir. Şekil 6 ya göre mezunların $\% 57$ sinin verilen lisans eğitimini yeterli bulmadıkları anlaşılmaktadır. Bu yetersizlik oranı, içerisinde birçok nedeni barındırabilmektedir. Akademik personelin yeterliliği, müfredatın güncelliği, sosyal imkânların tatmini bu nedenlerin başında gelebilmektedir. İlerleyen kısımlarda verilen cevaplardan hareketle daha net bir yorum yapmak mümkün olacaktır.

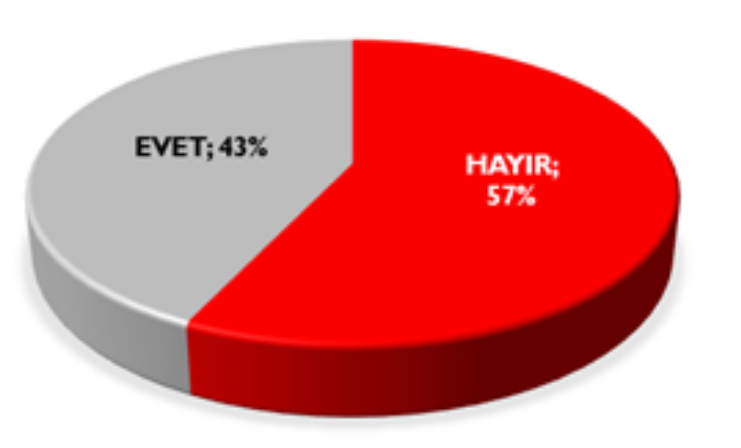

Şekil 6. Lisans Eğitiminin Yeterliliğine İlişkin Anket Sonuçları

Mezunlara, endüstri mühendisliği eğitimine ait müfredatın güncellenmesine ilişkin görüşleri sorulmuş, şekil 7 deki sonuçlara göre katılımcıların \%87’i bu konuda güncellenmesi gerektiği yönünde görüşlerini bildirmişleridir. Bu sonuç aslına birçok probleminde göstergesi olmaktadır.

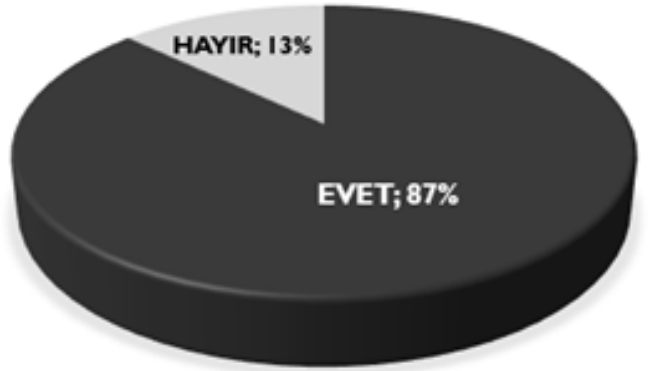

Şekil 7. Akademik Müfredatın Güncellenmesine İlişkin Bilgiler

Ankete bölüm 2'nin girişinde de belirtildiği üzere 67 farklı üniversiteden 224 mezun katılmıştı. Mezunların yaklaşık \% 87 'nin bu görüş̧e olması ve bir fikir birliğine varması, ilgili eğitim müfredatının iş hayatındaki gereksinimleri karşılamakta yetersiz olduğunu, alınan eğitimin teoride kaldığını ve uygulamadan uzak olduğunu, öğrencilerin bilgilerini tam olarak iş hayatına aktaramadıklarını ya da eğitimin tam olarak verilmediği gibi birçok temel problemi içinde barındırabilmektedir. 
Üniversitelerdeki akademik kadroların yeterliliği ve öğretim görevlilerinin konulara hâkimliği hakkındaki değerlendirmeler ise şekil 8 ve 9 da belirtilmiştir. Şekil 8 e göre "Dersi Anlatan Öğretim Üyelerinin Konulara Hâkim Olduğunu Düşünüyor Musunuz?" sorusuna katılımcıların \%68 i olumlu görüş belirtmiş, \%32 si ise olumsuz görüş belirtmiştir.

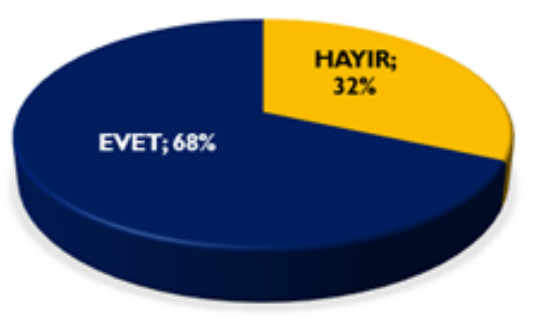

Şekil 8. Öğretim üyelerinin derse hakimliği.

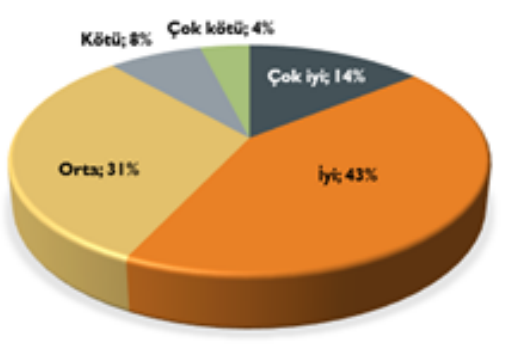

Şekil 9. Akademik Kadronun Yeterliliğinin Tespiti

Şekil 9 da ise "Eğitim Aldığınız Üniversitenin Akademik Kadrosunu Nasıl Değerlendirirsiniz?" sorusuna katılımcıların \%43 ü iyi, \%31' i orta ve \%14 ü ise çok iyi görüşlerini iletmiştir. Bu iki şekilden hareketle endüstri mühendisliği alanında Türkiye' de eğitim veren öğretim görevlilerin iyi ve üzeri derecelerde puanlandırıldığ anlaşılmaktadır. Ayrıca bu sonuç lisans eğitimin yeterliliğinin değerlendirilmesinde öğretim görevlilerin etkisinin daha az olduğu, bu yetersizliğin temelde başka problemlerden kaynaklandığı anlaşılmaktadır.

“Üniversitenizin Asistanlarını yeterli buluyor musunuz?” sorusuna ise şekil 10’ a göre katılımcıların \%41,5’ u orta, \%26,3' ü iyi, $\% 7,6$ ' sı ise çok iyi olarak değerlendirmişlerdir. Bu sonuca göre katılımcılar açısından asistanların yeterliliği, orta ve üzeri düzeyde olmakta, asistanların daha yeterli olmak adına biraz daha çaba sarf etmesi gerektiği anlaşılmaktadır.

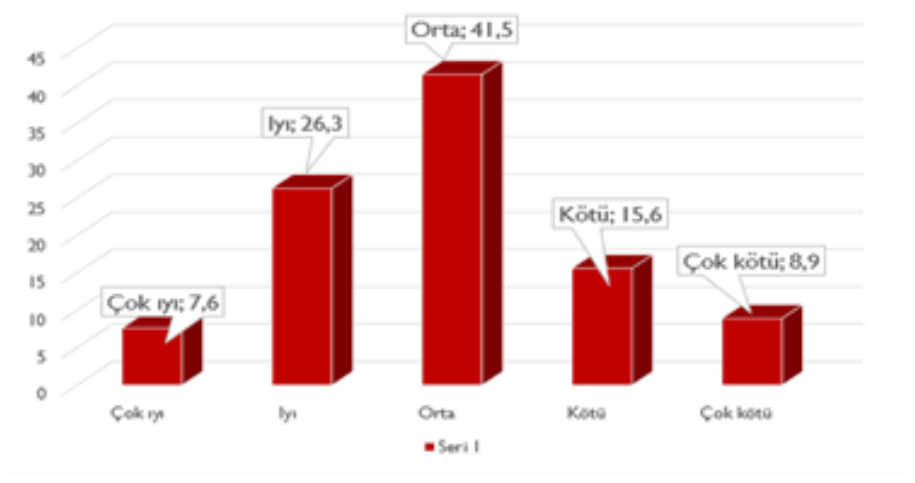

Şekil 10. Asistan Kadrosunun Değerlendirilmesi

Üniversite eğitiminde öğretim görevlisi ve öğrenci arasındaki iletişim büyük bir önem arz etmekte, bu ilişki öğrencinin dersteki başarısı başta olmak üzere özgüven, problem çözebilme, analitik çözüm yapabilme gibi birçok özelliğe etki edebilmektedir. Bu bağlamda “Öğretim Üyeleri ile Öğrenciler Arasındaki İletişim Nasıldı?" diye bir soru sorulmuş, elde edilen cevaplar ise şekil 11 de gösterilmiştir. Şekil 11 e göre katılımcıların, öğretim görevlileri ile orta ve iyi düzeyde bir ilişki kurduğu, bu durumda öğrencilerin, öğretim görevlileri ile rahat bir şekilde iletişim kurabildiğini belirtmektedir.

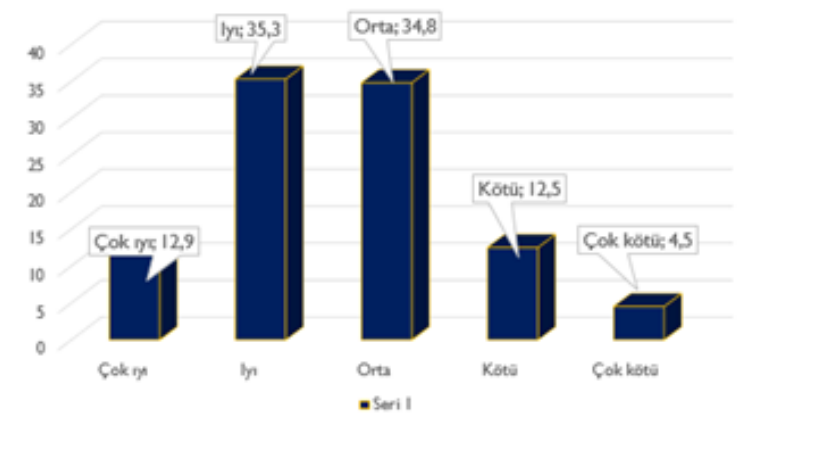

Şekil 11. Öğretim Üyesi-Öğrenci İletişimin Değerlendirilmesi.

Katılımcılara eğitim aldığınız bölümde projeli derslerin varlığı ve bunların hangi oranda etkili olduğu sorulduğunda, \%95 oranında projeli derslerin olduğunu ve bu derslerin oldukça faydalı olduğu sonucu ortaya çıkmıştır. Buna göre projeli derslerin öğrenmeyi kolaylaştırdığı ve iş hayatında daha faydalı olduğu düşünülmektedir. 

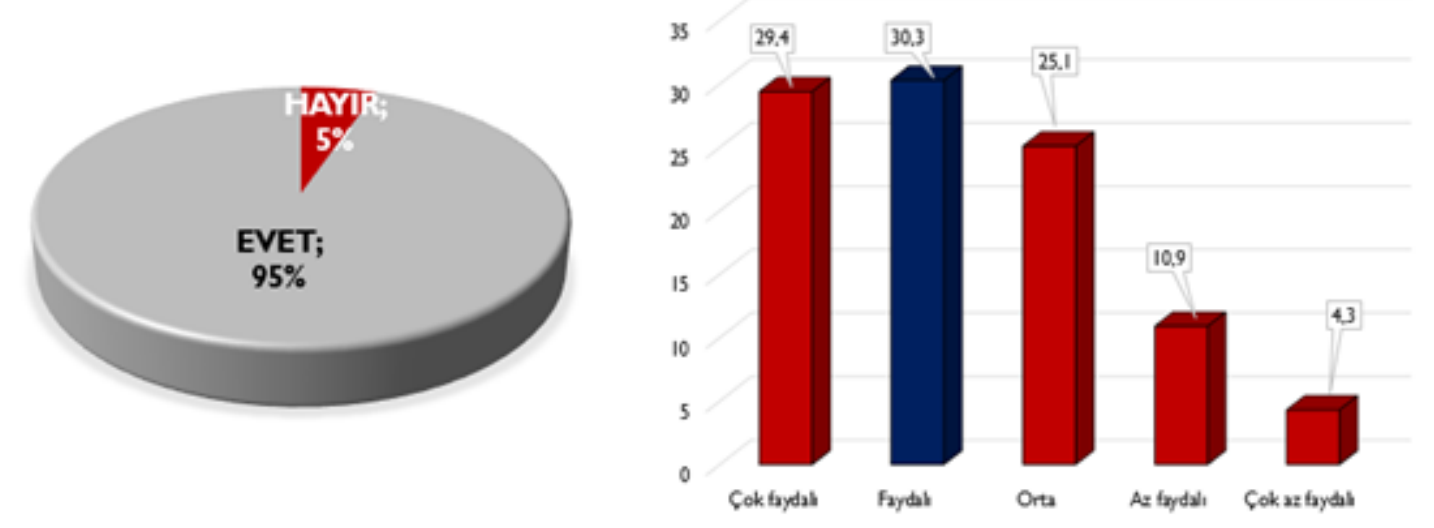

Şekil 12. Endüstri Mühendisliği Bölümünde Verilen Projeli Derslerin Faydasının Değerlendirilmesi

$\mathrm{Bu}$ sorulara ek olarak lisansüstü açısından üniversite ve mezunların durumunu görmek adına lisansüstü eğitimi ile ilgili olarak birkaç soru katılımcılara yöneltilmiştir. Şekil 13' de ankete katılan mezunların \%66,5' u lisansüstü eğitimi almadığını, \%33,5' u ise lisansüstü eğitimi aldıklarını ifade etmişlerdir.

\section{Lisansüstü Eğitimi Aldınız mı?}
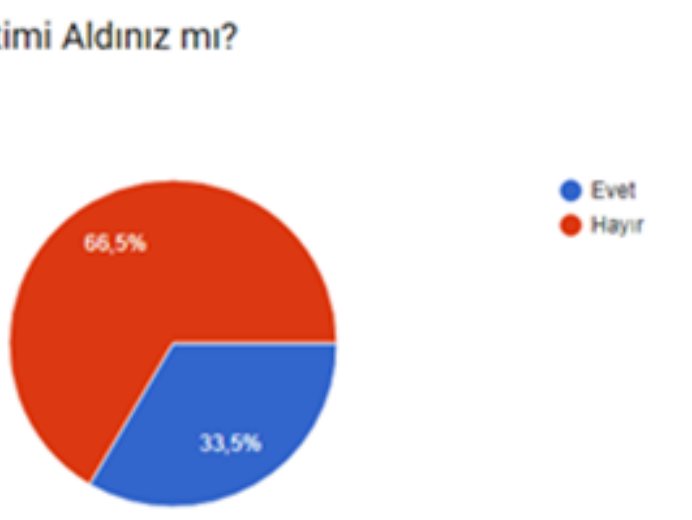

Şekil 13. Lisansüstü Mezunu Katılımcı Sayısı.

Lisansüstü eğitimi alınan üniversitenin yeterliliğini değerlendirmek için katılımcılara "Lisansüstü eğitimi aldığınız üniversitenin eğitimi nasıldı?" sorusu yöneltilmiş ve elde edilen sonuçlar şekilde 14' de belirtilmiştir. Şekil 14, 15 ve 16' da 1 (çok kötü), 2(kötü), 3(orta), 4(iyi) ve 5(çok iyi) ölçeğine karşılık gelmektedir. Şekil 14' deki sonuca göre, katılımcıların lisansüstü eğitim konusunda üniversiteleri orta-iyi arası bir düzeyde gördükleri anlaşılmıştır.

\section{Lisansüstü Eğitimi Aldığınız Üniversitenin Eğitimi Nasıldı?}

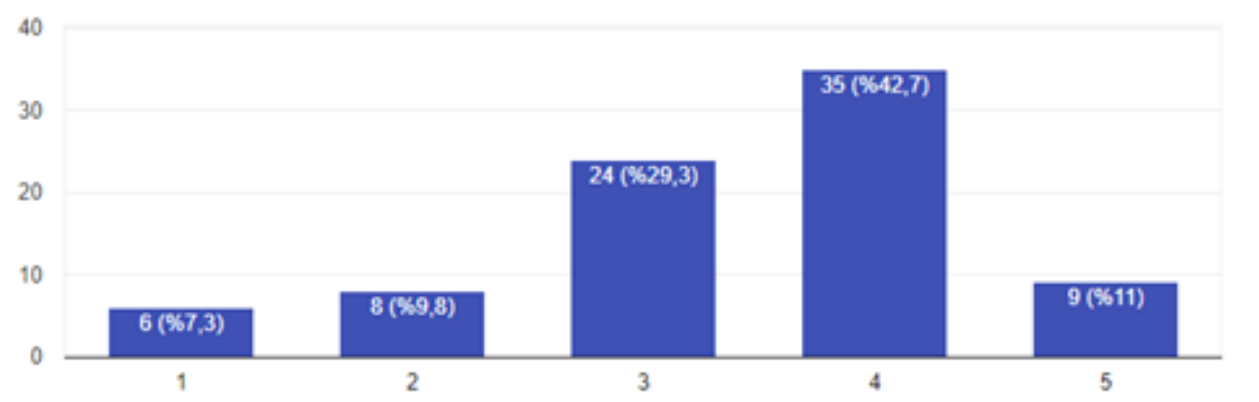

Şekil 14. Lisansüstü Eğitim Alınan Üniversitenin Mezunlar Açısından Değerlendirilmesi

Alınan lisansüstü eğitimde öğretim üyelerinin, öğrencilerine ne düzeyde katkı sağladıklarını görmek adına, "Lisansütü eğitiminde öğretim üyelerinin katkısı nasıldı?" sorusu yöneltilmiş ve şekil 15' de belirtilen sonuçlara göre lisansüstü eğitiminde öğretim üyelerin orta-iyi arası bir düzeyde öğrencilere yardımcı olduğu sonucu ortaya çıkmıştır. 


\section{Lisansüstü Eğitiminde Öğretim Üyelerinin Katkısı Nasıldı?}

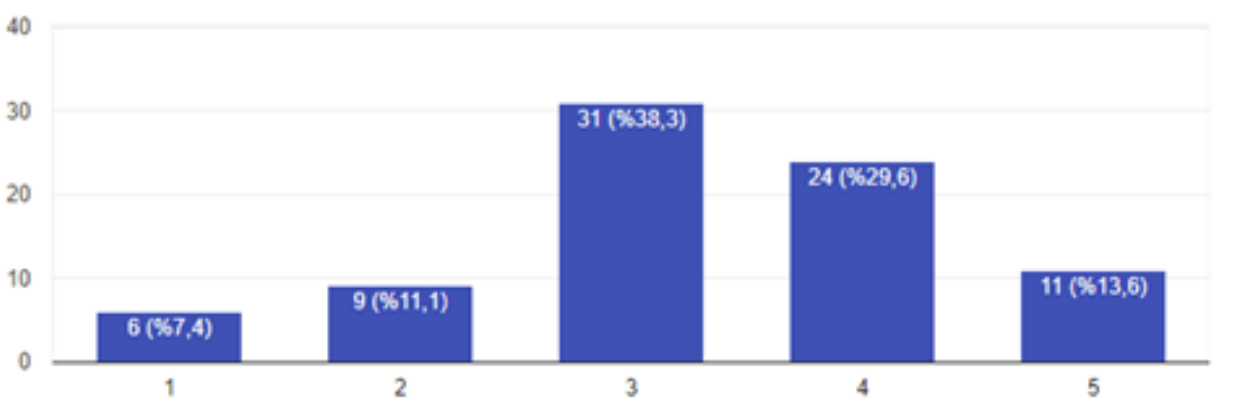

Şekil 15. Lisansüstü Eğitiminde Öğretim Üyelerinin Katkısı

Şekil 14 ve 15' deki sonuçlardan, katılımcıların lisansüstü eğitimi alırken, öğretim üyelerinin yeterli düzeyde katkı sağladığı anlaşılmaktadır. Son olarak da alınan lisansüstü eğitimin bireyin başarısına olan etkisini tespit etmek adına bir soru sorulmuş ve elde edilen cevaplar şekil 16’ da gösterilmiştir. Bu sonuca göre lisansüstü eğitiminin bireyin başarısına önemli bir düzeyde etki ettiği anlaşılmıştır.

\section{Lisansüstü Eğitiminizin Bugünkü Başarınıza Olan Katkısı Nedir?}

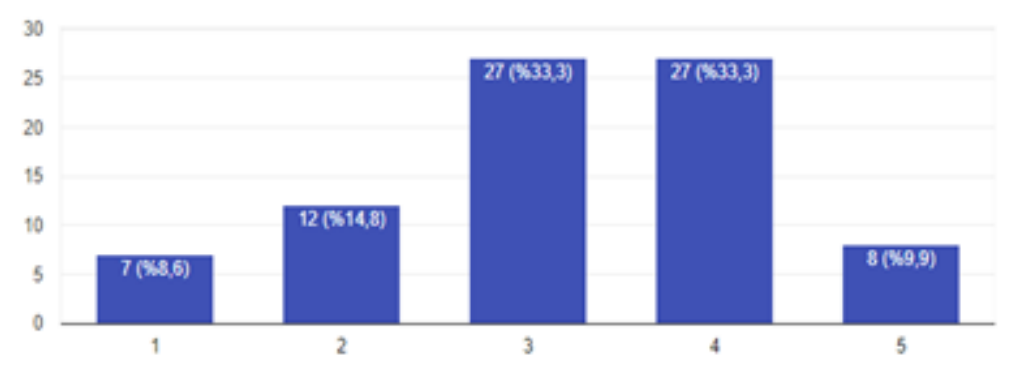

Şekil 16. Lisansüstü Eğitiminin, Başarıya Etkisi

Çalışmanın buraya kadar olan kısmında endüstri mühendisliği alanında alınan lisans ve lisansüstü eğitiminin değerlendirilmesi yapılmış, bir sonraki bölümde ise mezunların talepleri ve sektörün ihtiyaçları açısından endüstri mühendisliği bölümünün mevcut durumu analiz edilmiştir.

\subsection{Endüstri Mühendisliği Mezunlarının İsteklerine ve Sektörün Taleplerine İlişkin Anket Sonuçlarının Analizi}

Bu bölümde, endüstri mühendisleri mezunlarına, mezun oldukları üniversitelerin kendilerini tatmin edip etmedikleri, sektörde ihtiyaç duyulan programlar, endüstri mühendisliği bölümünde avantaj ve dezavantajlara sahip olan donanımlar gibi çeşitli sorular yöneltilmiş ve Türkiye' deki endüstri mühendisliği bölümlerinin öğrenciyi tatmin etme düzeyleri tespit edilmeye çalışılmıştır.

Ankette katılımcılara “Mezun Olduğunuz Üniversite Beklentilerinizi Karşıladı Mı?” sorusu iletilmiş ve elde edilen cevaplar şekil 17 de gösterilmiştir. Şekil 17' ye göre katılımcıların \%52' si bu soruya olumsuz cevap belirtirken, \%48'i olumlu cevap belirtmiştir. Bu durum bize öğrencilerin, mezun oldukları üniversitelerden beklentileri karşılanmış bir şekilde ayrılmadıklarını göstermektedir. Bu memnuniyetsizliği altında üniversitenin sağlamış olduğu sosyal ve yaşamsal imkânlar, güvenlik, kütüphane imkânları, laboratuvar imkânları ve ulaşımda yaşanan problemler gibi birçok etmen yatabilmektedir. Üniversitelerin buna neden olan problemleri tespit edip iyileştirmesiyle daha memnun bireylerin mezun edilebileceği düşünülmektedir.

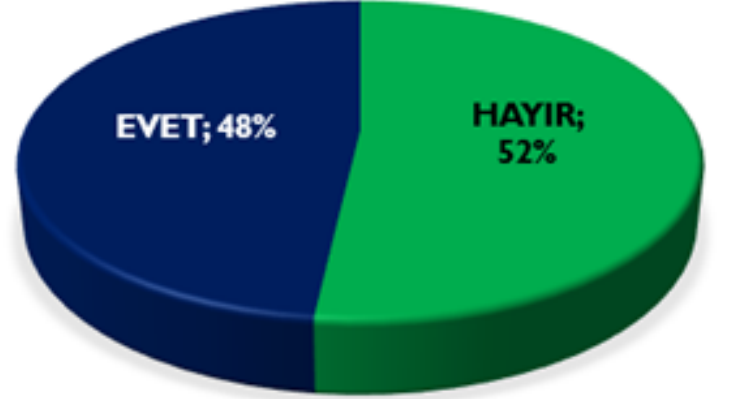

Şekil 17. Mezun Olunan Üniversitenin Öğrenci Beklentilerini Karşılama Durumu 
Katılımcılara “Üniversiteniz Size Vizyon Kattı Mı?” diye sorulduğunda katılımcıların \%60’ 1 olumlu görüş bildirirken, \%40’ 1 olumsuz görüş bildirmektedir. Bu sonuçlar katılımcıların, üniversiteye girdikleri zamana kıyasla mezun olduklarında farklı bir bakış açısı, bilgi birikimi ve donanımla sahip olduklarını göstermektedir.

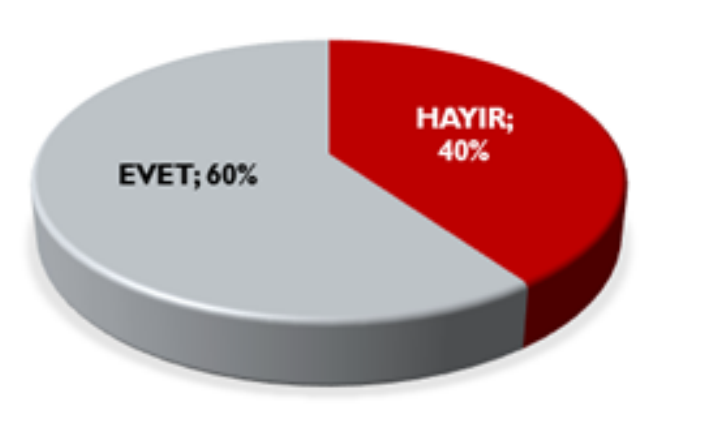

Şekil 18. Üniversiteniz Size Vizyon Kattı Mı? Sorusuna İlişkin Anket Cevapları

Ankette mezun öğrencilere "Mezun Olduğunuz Bölümü Hangi Üniversitede Okumak İsterdiniz?” diye sorulduğunda büyük bir çoğunluğun ilgili bölümü ait eğitimi başka bir üniversitede almak istediklerini göstermekte, bu durum mezunlar ile üniversiteler arasında bir sahiplenme-bağlılık kültürünün oluşmadığını göstermektedir. Şekil 19'e göre katılımcıların \%29' u Boğaziçi Üniversitesinde, \%22,3’ ü ODTÜ’ de, \%19,6’ ss ise İTÜ de endüstri mühendisliği eğitimini almak istemektedir.

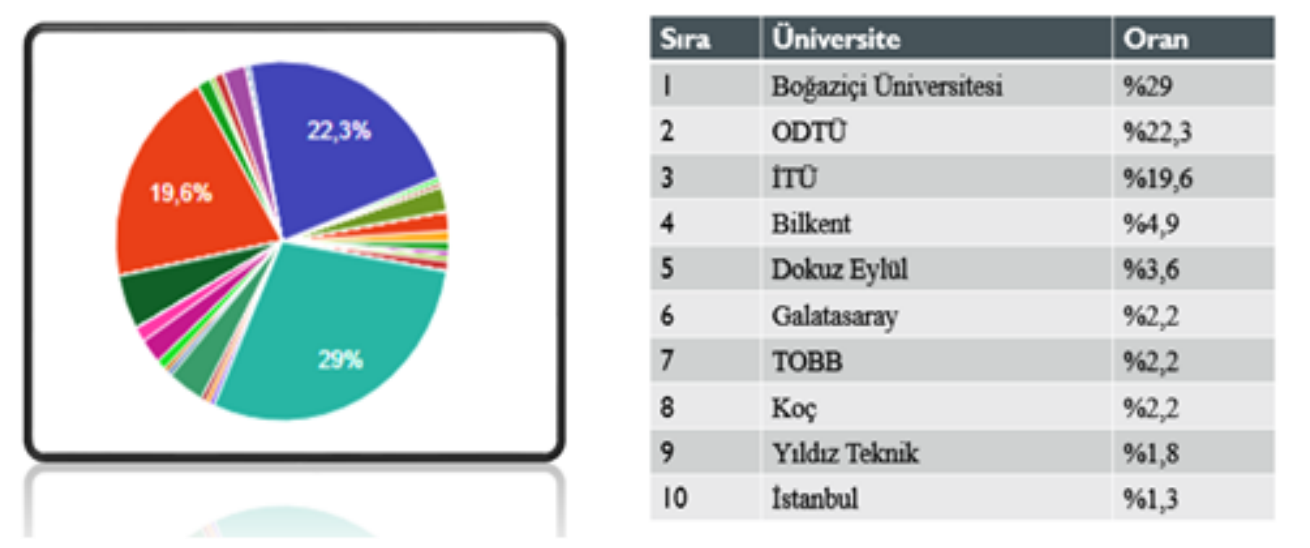

Şekil 19. Mezunların Okumak İstedikleri Üniversitelere İlişkin Anket Sonuçları

Mezunlara en iyi endüstri mühendisliği eğitimi veren üniversiteler hangisi diye sorulduğunda, katılımcıların \%32,1' i ODTÜ, \%29,9' u Boğaziçi, \%18,3'ü ise İTÜ olduğunu belirtmişlerdir. Şekil 19 ve şekil 20' deki sonuçlardan ODTÜ, Boğaziçi ve İTÜ' nün katılımcıların görüşleri açısından Türkiye'deki endüstri mühendisliği eğitimi alanında en fazla istenen ve başarılı bulunan üniversiteler olduğu anlaşılmaktadır.

\begin{tabular}{|l|l|l|}
\hline Sıra & Öniversite & Oran \\
\hline $\mathbf{1}$ & ODTO & $\% 32,1$ \\
\hline $\mathbf{2}$ & Boğaziçi & $\% 29,9$ \\
\hline $\mathbf{3}$ & ITU & $\% 18,3$ \\
\hline 4 & TOBB & $\% 3,1$ \\
\hline $\mathbf{5}$ & Koc & $\% 3,1$ \\
\hline 6 & Bilkent & $\% 2,7$ \\
\hline 7 & Kınkkale & $\% 1,8$ \\
\hline 8 & Galatasaray & $\% 1,8$ \\
\hline 9 & Yildız Teknik & $\% 1,3$ \\
\hline 10 & Balıkesir & $\% 1,3$ \\
\hline
\end{tabular}

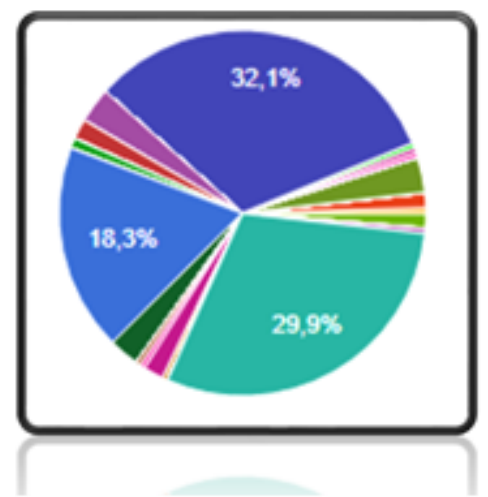

Şekil 20. Size Göre En İyi Endüstri Mühendisliği Eğitimi Veren Üniversite Hangisidir?

Üniversitelerde verilen eğitimin iş hayatında ne kadar etkili olduğu, sektörle ne kadar örtüştüğü ancak ilgili bölüm mezunlarının iş hayatına geçmeleri ile anlaşılmaktadır. Bu kapsamda iş hayatında endüstri mühendislerinin en fazla ihtiyaç duydukları programları belirlemek adına "Bir Endüstri Mühendisinin Bilmesi Gereken Bilgisayar Programları Nelerdir?" diye sorulduğunda elde edilen cevaplar şekil 21' de gösterilmektedir. 

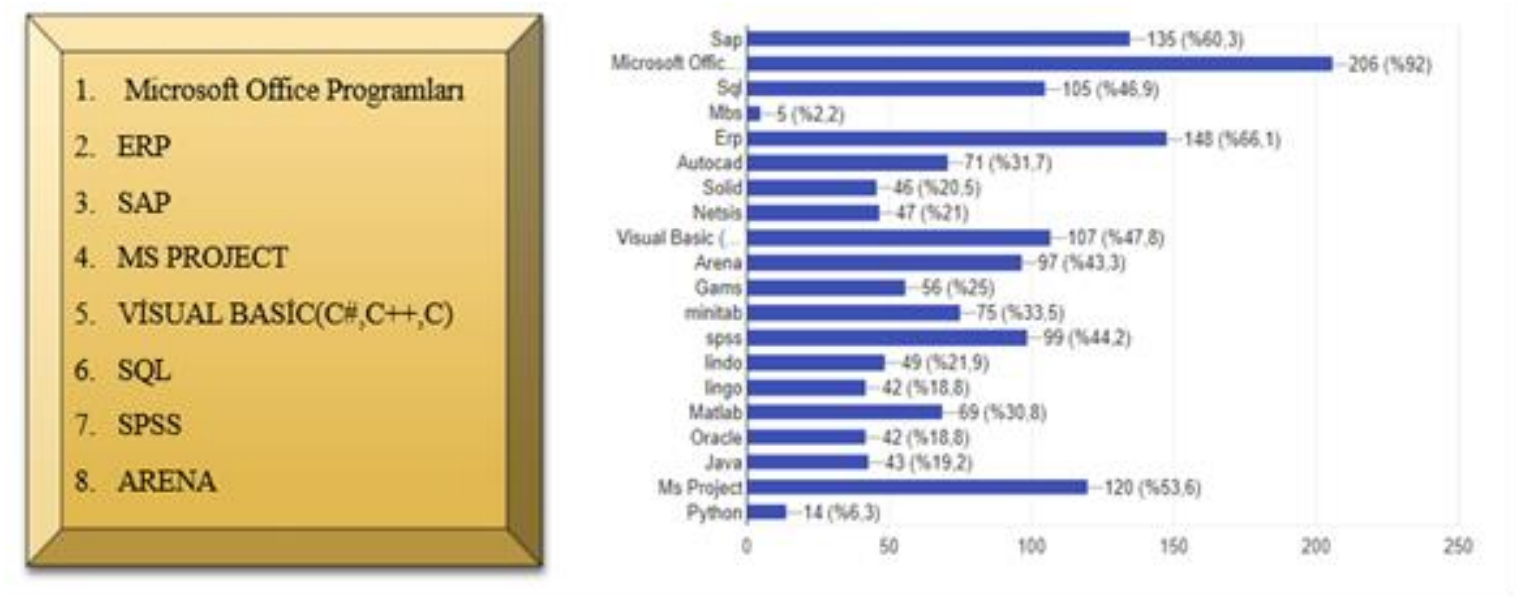

Şekil 21. Endüstri Mühendislerinin Bilmesi Gereken Programlara İlişkin Anket Cevapları

Şekil 21'deki sonuçlarda iş hayatında en fazla Office programlarına, daha sonra ERP-SAP gibi kurumsal kaynak planlaması programlarına ve MS-Project gibi proje tabanlı programlara ihtiyaç duyulduğu anlaşılmaktadır. Bu bağlamda endüstri mühendisliği eğitiminin sektörün talepleri doğrultusunda güncellenmesinin mezunların daha donanımlı olması ve sektörde başarılı olması adına büyük katkı sağlayacağı öngörülmektedir.

İlgili bölüm ve üniversitenin avantajları ve dezavantajlarını değerlendirmek adına katılımcılara üniversitenizin olumsuz ve olumlu yanları nedir diye sorulduğunda ortaya çıkan sonuçlar şekil 22 ve şekil 23 de gösterilmektedir. Katılımcılara göre ilgili bölümlerler de en fazla eksikliğin İngilizce eğitiminin yetersiz oluşu, Uygulamalı Derslerin azlığı ve Sosyal İmkânların eksikliği konularında yaşandığı, en fazla olumlu görünen özelliğin ise kütüphane imkânları konusunda yaşandığı anlaşılmaktadır.

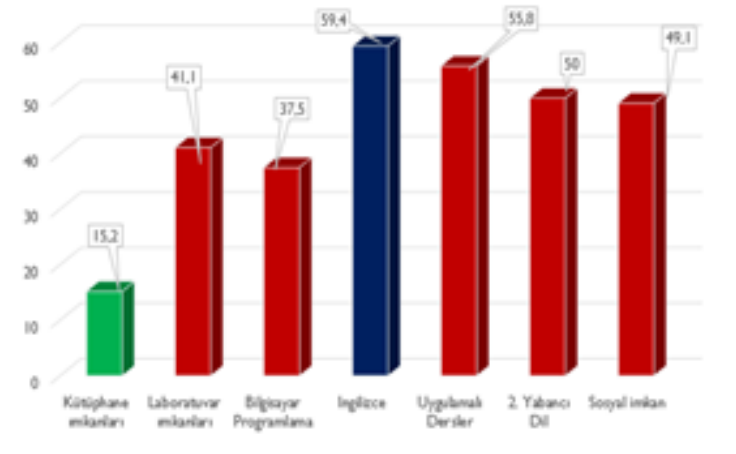

Sekil 22. Üniversitenizin Olumsuz Yanları

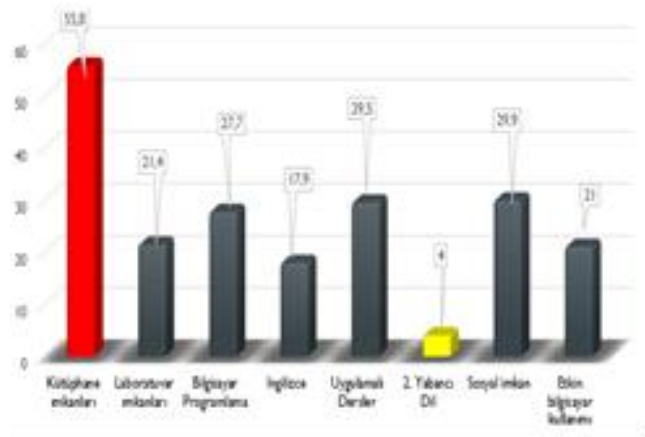

Şekil 23. Üniversitenizin Olumlu Yanları

Mühendislik öğrencilerinin lisans eğitimi hayatında en fazla karş̧laştığı problemlerden biri staj yeri bulma konusudur. Katılımcılara “Üniversiteniz Staj Bulma Konusunda Yardımcı Oldu Mu?” diye sorduğumuzda mezunların \%78'i bu soruya hayır, \%22' si ise evet cevabını vermiştir. Üniversitelerin, öğrencilerine bu konularda daha yardımcı olması, öğrencilerin daha mutlu mezun olmasını sağlayacak ve kaliteli yerlerde staj yapmalarına zemin hazırlayacaktır.

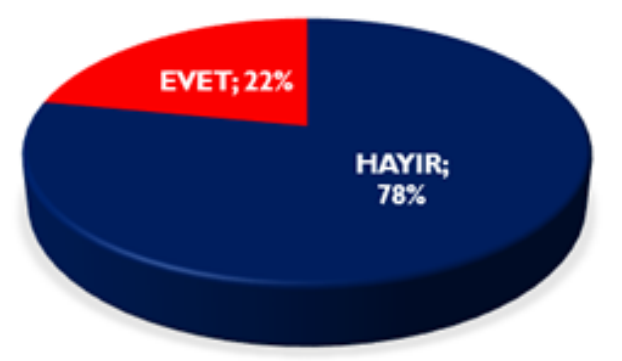

Şekil 24. Üniversiteniz Staj Yeri Bulmada Size Yardımcı Oldu Mu?

Endüstri mühendisliği bölümünün gelecek on yıl içerisinde hangi doğrultuda gelişeceğini tespit etmek için mezunlara "Endüstri Mühendislerinin Gelecek 10 Yılda Çalışabileceği Alanlar Nelerdir?" diye sorduğumuzda ortaya çıkan cevaplar şekil 25 de gösterilmiştir. 


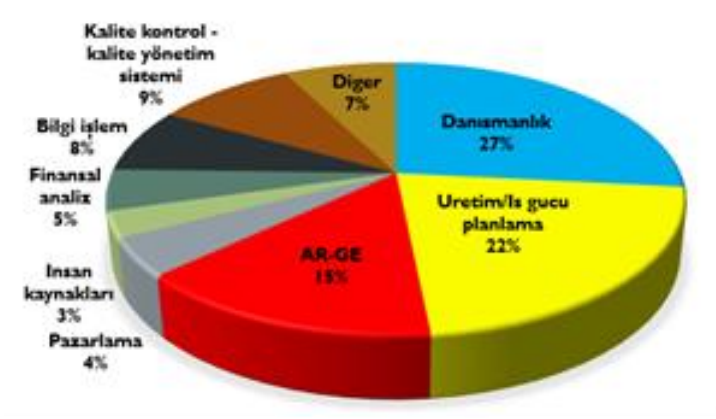

Şekil 25. Endüstri Mühendislerinin Gelecek On Yılda Çalışabileceği Alanlar.

Şekil 25' e göre katılımcılar, endüstri mühendislerinin gelecek on yıl içerisinde $\% 27$ oranı ile en fazla danışmanlık firmalarında, $\% 22$ oran ile üretim planlama-kontrol alanında ve \%13 oranı ile AR-GE alanında çalışacağını öngörmektedir. Bu durum, endüstri mühendislerine verilen lisans eğitiminin tekrardan güncellenip sektörün ihtiyaç duyduğu özelliklerde mühendis yetiştirilmesi gerektiğini belirtmektedir.

Türkiye' deki endüstri mühendisliği mezunu öğrencilerin özgüvenlerini tespit etmek ve kendilerini hangi seviyede gördükleri belirlemek adına, katılımcılara "Mezun Olduğunuzda Uluslararası Düzey-de Çalışabilecek Donanımda Olduğunuzu Düşünüyor Musunuz?" sorusunu yönelttiğimizde elde ettiğimiz sonuçlar şekil 26 da gösterilmiştir.

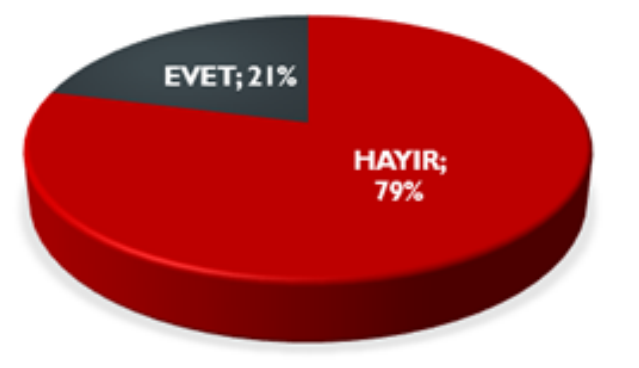

Şekil 26. Mezun Olduğunuzda Uluslararası Düzeyde Çalışabilecek Donanımda Olduğunuzu Düşünüyor Musunuz Sorusuna Verilen Anket Cevapları

Şekil 26' daki sonuçlara göre katılımcıların \%79'u bu soruya hayır cevabını vermiştir. Bu durum ciddi bir problemin göstergesidir. Bu göstergenin birçok nedeni olabilmektedir. Bu nedenlerden bazıları aşağıda verilmiştir.

- Öğrencinin mesleki bilgisini tam olarak alamamıș olması.

- Öğrencinin üniversitede aldığı eğitimin teoride kalması ve gerçek hayat uygulamalarından yoksun olması.

- Öğrencinin uluslararası düzeyde kendini ifade edebilecek dil seviyesine (özellikle İngilizce) sahip olamaması.

- Üniversite hayatı boyunca öğrencinin sürekli derslerle uğraşması ve sosyal yönünün sınırlı kalması.

- Öğrencinin kendi özelliklerinin farkında olamaması ve özgüven eksikliği.

Ankette üniversitelerin bahar şenliklerine desteğini görmek adına "Üniversitenizde Bahar Şenlikleri Yapılıyor Mu?" sorusu yöneltilmiş ve elde edilen sonuçlar şekil 27' de gösterilmiştir. Şekil 27'e göre Türkiye' deki üniversitelerin \%80' i bahar şenliği yapmaktadır.

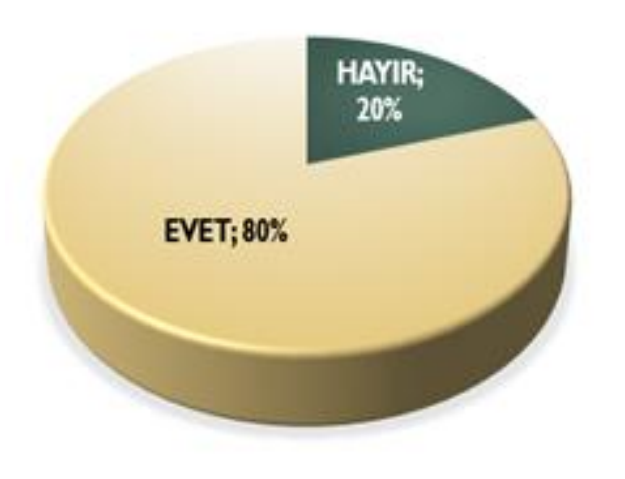

Şekil 27. Üniversitelerde Bahar Şenliklerinin Yapılma Durumu 
Buraya kadar olan kısımda yapılan anket sonuçları detaylı bir şekilde analiz edilmiş ve bazı çıkarımlarda bulunulmuştur. Çalışmanın üçüncü bölümünde elde edilen sonuçlar istatistiksel açıdan yorumlanmış ve bu sonuçlara neden olan sebepler arasındaki ilişkiler araştırılmıştır.

\section{ANKET SONUÇLARININ ISTATISTIKSEL ANALIZí}

$\mathrm{Bu}$ bölümde ankete verilen cevaplara dayalı olarak birtakım istatistiksel çıkarımlar yapılmış ve anket sonuçlarının yorumlanmasında çeşitli istatistiksel yöntemlerden yararlanılmıştır.

\subsection{Anket Sonuçlarının İstatistiksel Analizi}

Anket çalışması sonucu elde edilen çıktılara dayalı olarak birçok istatiksel çıkarım yapılabilmekte ve farklı bu bağlamda çeşitli istatistiksel yöntemler kullanılabilmektedir. Bu çalışma kapsamında yapılan çıkarımlar ve kullanılan istatistiksel yöntemler aşağıdaki gibidir.

\section{Lisansüstü Ve Lisans Mezunlarının, Akademik Kadro Değerlendirme Ortalamalarının Aynı Olup Olmadığı.}

Lisansüstü mezunu katılımcılar ile lisans mezunu katılımcıların akademik kadroyu değerlendirme konusunda aynı fikre sahip olup olmadıklarını belirlemek adına, bağımsız örneklem t-testine dayalı bir analiz çalışması yapılmıştır. Bağımsız örneklem ttestinde, tek örneklem t-testinden farklı olarak iki ayrı grubun ortalamaları karşılaştırılması ve bu ortalamalar arasında anlamlı bir farklılık olup olmadığının belirlenmesi için bu yönteme başvurulmuştur. Örneğin kızlar ile erkeklerin üniversite giriş sınavlarındaki başarılarının karşılaştırılmasında bağımsız örneklem t-testi kullanılabilmektedir. İlgili testin yapılmasında ve çalışmada içerisinde yapılan tüm testlerde SPSS 15.0 programı kullanılmakta ve bu program yardımıyla aşağıdaki hipotez test edilmektedir.

H0 hipotezi: Lisansüstü ve lisans mezunlarının, akademik kadro yeterliliğini değerlendirme ortalamaları aynıdır. H1 hipotezi: Lisansüstü ve lisans mezunlarının, akademik kadro yeterliliğini değerlendirme ortalamaları aynı değildir.

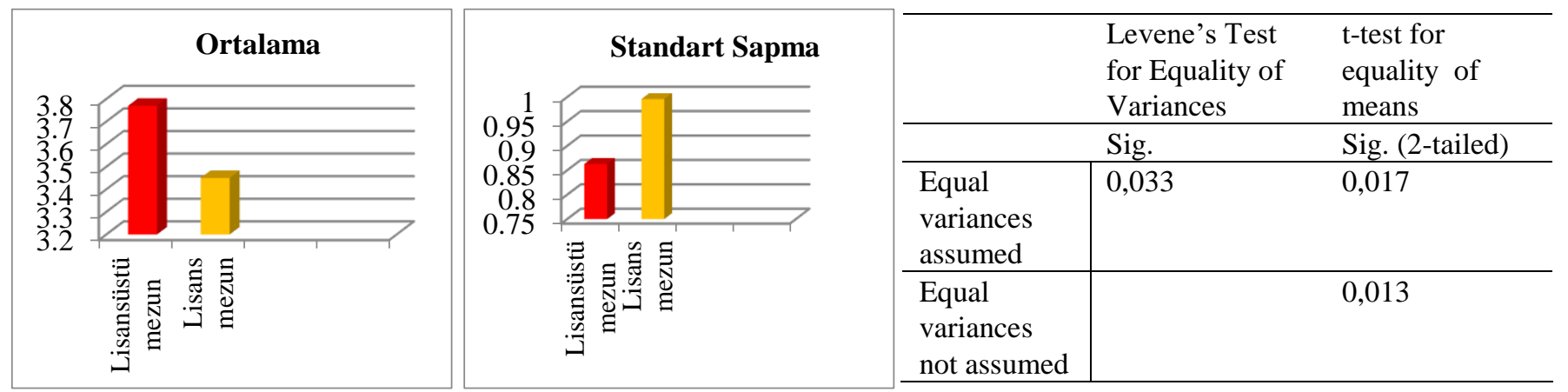

Şekil 28. Lisansüstü ve Lisans Mezunlarının Akademik Kadro Değerlendirmesine İlişkin SPSS Çıktısı

Şekil 28' e baktığımızda, Lisansüstü Ve Lisans Mezunlarının, Akademik Kadro Değerlendirme Ortalamaları aynı değildir. Lisansüstü mezunlar, akademik kadroyu daha yeterli bulmaktadır. Ayrıca iki gurubun varyanslarının eşit olmadığı ilgili şekilden anlaşılmaktadır.

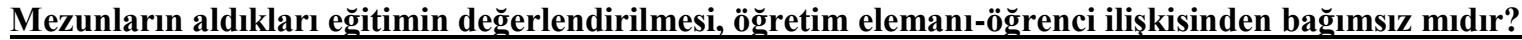

Ankette soruya cevap verirken bireye etki eden birçok faktör bulunabilmektedir. Katılımcıların aldıkları eğitim değerlendirmesine de etki eden birçok faktör bulunabilmektedir. Öğretim elemanı-öğrenci ilişkisi de bu faktörlerden biri olabilmektedir. İstatistikte iki değişken arasında ilişki olup olmadığını kontrol etmek için çapraz tablolar yöntemi kullanılmaktadır. Bu bağlamda mezunların aldıkları eğitimi değerlendirirken, öğretim elemanı-öğrenci ilişkisinin bir etkisinin olup olmadığı çapraz tablolar yardımıyla anlaşılmakta ve arasındaki ilişki Ki-kare testi ile belirlenmeye çalışılmaktadır. İlgili test için kurulan hipotez ise aşağıda ifade edilmektedir.

H0: Mezunların aldıkları eğitimin değerlendirilmesinde, öğretim elemanı-öğrenci ilişkisinin bir etkisi yoktur.

H1: Mezunların aldıkları eğitimin değerlendirilmesinde, öğretim elemanı-öğrenci ilişkisinin bir etkisi vardır.

Yapılan analiz sonucunda Pearson Chi-Square için anlamlılık düzeyi 0.005 çıkmıştır. Bu değer 0.05 den küçüktür ve bu nedenden dolayı H0 hipotezi reddedilir. Yani alınan lisans eğitiminin değerlendirilmesinde, öğretim elemanı-öğrenci ilişkisi etkili bir faktördür. 
Anket çalışmasında birçok değişken bulunabilmekte ve bu değişkenler arasındaki ilişkinin ne düzeyde olduğunu, birbirlerini olumlu mu ya da olumsuz mu etkilediklerinin bilinmesi istenmektedir. İstatistikte değişkenler arasındaki ilişkinin yönünün ve şiddetinin belirlenmesinde ise "korelayon analizi" kullanılmaktadır. Çalışma içerisinde eğitim alınan üniversitenin akademik kadroları değerlendirilmesinde öğretim elemanı-öğrenci ilişkisinin hangi yönde ve ne düzeyde ilişkili olduğunun belirlenmesinde korelasyon analizinden faydalanılmaktadır. Yapılan analiz sonucunda mezun öğrencilerin akademik yeterliliği değerlendirmesi ile öğretim elemanı-öğrenci ilişkisi arasında \%46,7 oranında yani orta düzeyde pozitif yönde anlamlı bir ilişki olduğunu görmekteyiz.

\section{$\underline{\text { Lisan eğitiminin yeterliliği ile Secmeli Dersler ve Projeli Dersler Arasındaki İlișkinin İncelenmesi }}$}

Anket çalışmasında bir sorunun değerlendirmesine etki edecek birden fazla değişken olabilmektedir. Burada herhangi bir değişkenin, diğer faktörlerden bağımsız olarak karara etki derecesinin belirlenmesi ve sorunun asıl sebebinin tespit edilmesi istenebilir. İstatistikte bir ya da birden fazla değişkenin etkisi kontrol altına alınarak iki değişken arasındaki ilişkinin belirlenmesinde "kısmi korelasyon analizi" kullanılmaktadır. Bu bağlamda, çalışma içerisinde lisan eğitiminin yeterliliği ile seçmeli dersler ve projeli dersler arasındaki ilişkinin incelenmesinde kısmı korelasyon analizinden faydalanılmaktadır.

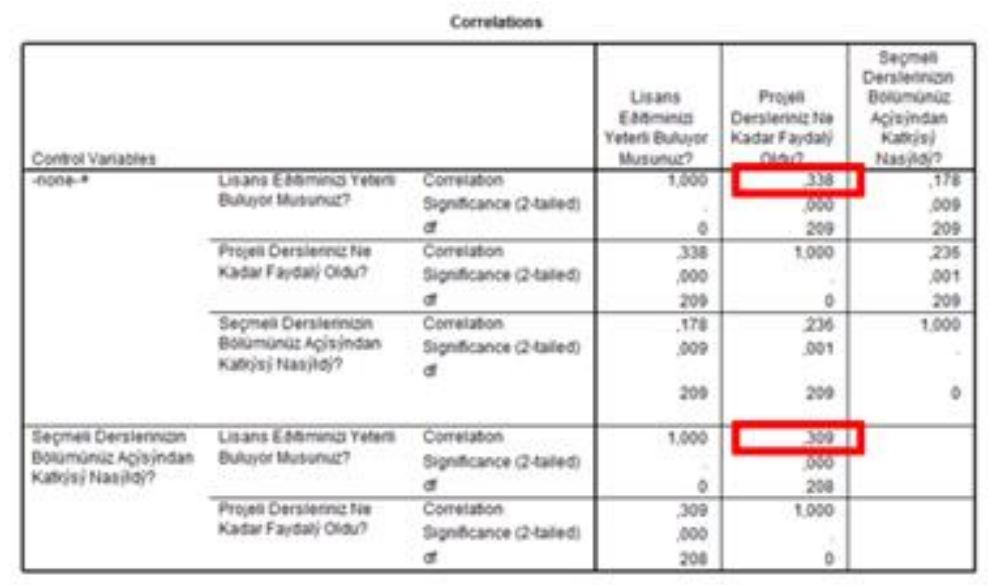

Şekil. 29. Lisans Eğitiminin Yeterliliği ile Seçmeli Dersler ve Projeli Dersler Arasındaki İlişkinin İncelenmesine Ait SPSS Çıktısı

Şekil 29’ daki sonuçlara göre, lisans eğitimi ile projeli dersler arasında, seçmeli derslerin etkisi kontrol altına alındığında, pozitif yönlü, anlamlı ve zayıf bir ilişki olduğu, seçmeli derslerin ise projeli dersler ve lisans eğitimi üzerinde düşükte olsa bir etkiye sahip olduğunu anlaşılmaktadır.

\section{ANKET SONUÇLARINA GENEL BİR BAKIŞ}

Bölüm 2' deki detaylı analiz ve bölüm 3' deki istatistiksel çıkarımlardan hareketle yapılan anket çalışmasına ilişkin genel bir değerlendirme yapılmış, tespit edilen problemler ile bunlara ilişkin bir takım önerile aşağıda maddeler halinde ifade edilmiştir.

- Mezunlar, genel olarak üretim sektöründe çalıştıkları için Microsoft Ofis ve ERP programlarına ihtiyaç duymaktadır. Bu nedenden dolayı Ofis ve ERP programlarının kullanılmasına ilişkin derslere olan eğilim artırılmalıdır.

- Office programları içerisinde Excel, en fazla ihtiyaç duyulan program olduğu tahmin edilmektedir. Bu kapsamda excel uygulamaları ile ilgili bir ders açılması, endüstri mühendisliği bölümü öğrencileri açısından oldukça faydalı bir işlem olacağı öngörülmektedir.

- Ankete katılanların \%87' si eğitim müfredatının güncellenmesi gerektiğini düşünmektedir. Teknoloji ve yazılım sektöründe meydan gelen gelişmeler, üretim başta olmak üzere tüm sektörleri etkilemekte, iş hayatında bu sistemleri algılayıp doğru bir şekilde yönetebilen mühendislere ihtiyaç duyulmaktadır. Bu durumların dikkate alınarak müfredatın güncellenmesi ve yeni derslerin eklenmesi gerekmektedir.

- Genel olarak üniversitelerde en olumsuz yönün İngilizce ile ilgili olduğu anlaşılmaktadır. Bu alanda iyileştirme çalışmalarının yapılması, öğrencinin daha donanımlı bir şekilde mezun olmasına zemin hazırlayacaktır.

- Öğrencilerin problem yaşadığı bir diğer konu ise staj bulma işlemidir. Genel olarak öğrenciler staj bulamamakta, buldukları yerde ise stajdan yeteri kadar fayda sağlayamamaktadır. Bölümlerin bu konuda öğrencilere yardımcı olması ile birlikte öğrenci daha az zorluk yaşayarak hatta hiç yaşamayarak okulunun uygun gördüğü yerde staj faaliyetine gerçekleştirebilecektir.

- Yapılan anket çalışmasında uygulamalı derslerin çok faydalı olduğu görülmektedir. Bu bağlamda derslerin uygulama ve proje tabanlı olmasının daha yararlı olacağı tahmin edilmektedir. 
- Öğrencilere endüstri mühendisliğinin öneminin daha iyi anlatılması ve kendi yeterliliklerinin farkında olması ile birlikte daha donanımlı ve özgüvenli endüstri mühendislerini yetiştirilebileceği öngörülmektedir.

- Mezunların büyük çoğunluğu üretim sektöründe çalışmaktadır. Bu bağlamda müfredatta üretim derslerine daha fazla ağırlık verilmeli ve dersler sektör uygulamaları ile daha fazla ilişkilendirilmelidir. Ayrıca bu alanla ilgili programların kullanımına ilişkin uygulama tabanlı dersler de verilmelidir.

$\mathrm{Bu}$ çıkarımların sayısı artırılabilmekte ve anket sonuçları farklı açılardan ele alınabilmektedir. Çalışma içerisinde tespit edilen durumlar ve bir takım öneriler yukarıdaki gibi olmakta, sonraki bölümde ise çalışma genel bir şekilde değerlendirilmekte ve sonraki çalışmalar için görüş ve öneriler sunulmaktadır.

\section{SONUÇ VE ÖNERILER}

Lisans eğitimi, bireylerin yaşam döngüsü içerisindeki önemli aşamalardan biridir. Bu aşamada insanların büyük çoğunluğu yaşamları boyunca yapacakları mesleğe ilişkin bilgiler almakta, iş hayatına hazırlanmakta, belirli bir kültür ve bakış açısına sahip olmaktadır. Bu süreci verimli şekilde geçiren öğrenciler iş hayatında daha özgüvenli ve başarılı olurken, verimsiz geçiren öğrenciler iş hayatında daha az başarılı olmakta ve ilerleyen yıllarda eksiklerini kapatmak için ciddi bir efor sarf etmektedir. Bireylerin özgüvenli ve başarılı bir şekilde iş hayatına hazırlanmasında ise üniversitelere ve ilgililere büyük bir görev düşmektedir. Alınan lisans eğitiminin yeterliliği, sosyal ve kültürel imkânlar, kütüphane-laboratuvar imkânları ve akademik kadronun tutumu, bireyin başarısına etki eden önemli etkenlerden bazılarıdır. Üniversite ve bölümlerin bu konulardaki başarısı ise ancak öğrenciler mezun olduktan sonra ve iş hayatına geçince anlaşllabilmektedir.

Bu çalışmada Türkiye'de endüstri mühendisliği eğitimi veren üniversitelerinin mezun görüşlerine dayalı olarak değerlendirebilmesi, ilgili eğitimin, bölümün ve üniversitelerin olumlu ve olumsuz yönlerin tespit edilebilmesi için mezun görüşlerine dayalı bir anket çalışması düzenlenmiştir. Anket çalışması sonucu elde edilen çıktılar detaylı bir şekilde analiz edilmiş, istatistiksel açıdan incelenmiş ve çeşitli çıkarımlarda bulunulmuştur. Sonuç olarak bu çalışma ile Türkiye' de verilen endüstri mühendisliği eğitiminin mevcut durumunun analiz edilmesi, eğitimdeki problemlerin belirlenmesi ve çözülmesi adına bir taslak oluşturulması amaçlanmıştır.

Gelecek çalışmalarda katılımcı sayısının artırılması, farklı değerlendirme ölçütlerin belirlenmesi ve çeşitli istatistiksel metotların kullanılmasıyla daha anlamlı ve faydalı sonuçların elde edileceği düşünülmektedir.

\section{BILLGILENDİRME}

Bu çalı̧̧ma Tubitak-BIDEB 2211 doktora burs programı tarafından desteklenmektedir.

\section{REFERANSLAR}

https://www.google.com.tr/search?q=\%C3\%BCniversite+e\%C4\%9Fitim\&rlz=1C1NDCM trTR717TR717\&source=lnms\&tbm= isch\&sa $=$ X\&ved=0ahUKEwiC5YSz467XAhWEOsAKHaMlANsQ AUIDCgD\&biw=1366\&bih=662\#imgrc=hzYidfsD59m4m M: (Erişim Tarihi: 13.01.2018),

Biles, W. E. (1991). The engineering science of industrial engineering: a viewpoint of the industrial engineering curriculum. IIE transactions, 23(3), 208-214.

Buzacott, J. A. (1984). The future of industrial engineering as an academic discipline. IIE Transactions, 16(1), 35-43.

Chen, C. K., Jiang, B. C., \& Hsu, K. Y. (2005). An empirical study of industrial engineering and management curriculum reform in fostering students' creativity. European Journal of Engineering Education, 30(2), 191-202.

Ellis, R. L., \& Pun, K. F.(2010). Future of industrial engineerıng traınıng at the university of the west indies: a currıculum proposal. 2nd Industrial Engineering and Management (IEM-2010) Conference

(https://www.researchgate.net/publication/287990311_FUTURE_OF_INDUSTRIAL_ENGINEERING_TRAINING_AT_THE_ UNIVERSITY OF_THE_WEST_INDIES_A_CURRICULUM_PROPOSAL Erişim Tarihi: 13.01.2018)

Elsayed, E. A. (1999). Industrial engineering education: A prospective. European Journal of Engineering Education, 24(4), 415 421

Ercan, S., Metin, B. C., \& Düzdar, İ. (2005). Endüstri mühendisliğine güncel bir bakış.

Erginel, N., Tekçe, M., Küçük, G., \& Alper, A. (2016). Türkiye'de endüstri mühendisliği mesleğine bilimsel açıdan bir bakış. Journal of Industrial Engineering (Turkish Chamber of Mechanical Engineers), 27(1). 
Köksal, G., \& Eğitman, A. (1998). Planning and design of industrial engineering education quality. Computers \& industrial engineering, 35(3-4), 639-642.

Kuo, W. (2003). The direction of education and research in industrial engineering. Journal of the Chinese Institute of Industrial Engineers, 20(2), 83-90.

Mummolo, G. (2007). The future for industrial engineers: education and research opportunities. European Journal of Engineering Education, 32(5), 587-598.

Schutte, C. S., Kennon, D., \& Bam, W. (2016). The status and challenges of industrial engineering in South Africa. South African Journal of Industrial Engineering, 27(1), 1-19.

Yaşar, M. (2014). İstatistiğe Yönelik Tutum Ölçeği: Geçerlilik Ve Güvenirlik Çalışması. Pamukkale Üniversitesi Eğitim Fakültesi, 36, 59-75. 